\title{
Determinant Factors of Finance for Petty Traders in the Informal Sectors: With References to Jimma Town, Oromia Region, Ethiopia
}

\author{
Fikremariam Zergaw Giref \\ MSc in ACFN, Lecturer at Wolaita Sodo University
}

\begin{abstract}
This paper examines factors that constrain petty traders' access to finance. Just like other urban centers of the country, the urban poor petty traders in Jimma town are engaged in different informal activities. Their participation is particularly concentrated in such activities as: small cafés, fabricated shoes and cloths, vegetable and fruit vending. The research identified and analyzed the major sources of capital for informal businesses and the problems faced in accessing business funds. The purposes of this study is to assess and analyze determinant factors of finance among informal petty traders in Jimma town. In order to achieve the intended objective, two types of sampling techniques i.e. (purposive and stratified sampling) were used and a sample of 182 informal petty traders were selected from three kebeles of the town. Namely, Bosakito,Hirmatamerkato and Ginjoguduru. The relevant data were gathered through questionnaire and observation and descriptive statistics were applied for the analysis purpose. The finding of the study revealed that most of the petty trade operators in Jimma town are in their productive age, having basic education, and came from out side of Jimma town (Specially from the nearest towns) in search of job opportunities. The study also came to detect that; the reasons for petty traders to be engaged in the informal activities were lack of alternatives to living, less start up capital and family problems. In addition to this, financial support from institutions and banks were not adequate enough for the petty traders due to various factors: like lack of collateral security, license requirement, bureaucratic process of financial institutions. In the study area no free loan service is granted, less awareness in the part of the petty traders how to acquire finance, and high interest rate are there. The researcher forwarded some constructive recommendations based on the findings detected to financial institutions and government authorities so as to provide better financial services for petty traders. Raising the awareness of large conventional commercial banks and also governments should adopt specific policies to bring informal firms under formal regulation. And providing training and awareness creation with regard to financial access information and other trading activities. In addition to this, the financial institutions need to provide financial services with low/ fair interest rate and providing non-interest bearing loan for those petty traders who are not volunteer topayinterest due to some religious or traditional doctrines.
\end{abstract}

Keywords: Petty Traders, Informal sectors, Financial Institutions

DOI: $10.7176 /$ RJFA/10-3-02

\subsection{Background of the Study}

Petty trading can be assumed to be an economic activity that involves selling (and buying) goods and services in small scale, ranging from agricultural produce to imported consumer goods. In this study context, petty trading constitutes a collection of individual sellers with small capital and buyers operating in a group of small spaces. Petty trading has increasingly got attention as one of important activities in urban development processes. In the early 1990s, for example, integrating petty trading in the urban economy was among the prioritized issues in implementing Environmental Planning Management (EPM) in Dares Salaam (Kombe, 2012).

The distinguishing characteristics of their economic activities have been delineated in a number of ways. The ILO Report on the Employment Strategy Mission to Kenya identified the general characteristics of informal sector activities as ease of access and entry, small scale, labor- intensive undertakings, usually familyowned, with a reliance on indigenous resources and informally acquired skills, and operating in unregulated, competitive markets. The model developed by Santos distinguished between upper and lower circuits of economic activity. The latter are seen to be labor intensive, having little dependence on overhead capital, negligible fixed costs and small inventories of goods and raw materials. (Sr. V Brand RSHM, Senior Lecturer, P. Bag 66022, Kopje. Harare, Zimbabwe). Petty trading activities can be perceived as a reflection of the prevailing socialeconomic realities of present-day cities, especially in third world economies. It can be argued that petty trading is a product of unprecedented urbanization, especially the failure by the formal employment and income generating sector to cater for the low-income households (UN Habitat, 2012). Petty trading in cities of developing countries therefore has an important role that cannot be ignored in the overall urban development and management processes as it provides employment opportunities accounting for 60 per cent of urban jobs (ibid), striving at attaining and sustaining livelihoods of many urban settlers, specifically low-income households (Anyamba, 2006).

Several authors, academics and bodies such as the International Labor Organization (ILO) and the World Bank have shown great interest and studied factors which affect the growth of informal business enterprises in various countries (Imani, 2012). The major hindering factors studied include capital shortage, poor management, 
technical and marketing skills. However, this study only reviews literature on the nature of financial problems affecting growth of informal business operations in developing countries with a special focus on Africa. The importance of informal business activities in the economic development of poor countries has been recognized in nearly all countries of the world (Imani, 2012). Harper (2006) asserts that there are several reasons why informal business operations merit attention especially in developing countries, labor being in excess, capital scarce and the means of production owned by a few foreign companies. Further, Harper (2006) argues that even in Great Britain they have explicit arrangements in favor of informal business operations.

Jenkins (2006) indicated that informal sector absorbs more than $70 \%$ of urban labor force in most African countries and those by Kobb (2005) shows that in Tanzania, alone, the informal sector contributes more than $90 \%$ of the country's Gross Domestic Product. Surprisingly, studies by Block (2011) and Gemini (2014) and Mandizvidza (2010) respectively show that informal economy constituted 15\% of Zimbabwe's Gross Domestic Product and $94 \%$ of the small scale businesses were informal. The inability of the formal sector to provide job for the growing labor force have resulted in the rise and expansion of unemployed people, who are forced to look for employment opportunities outside the formal (modern) sector. The poor especially women are engaged in the so called informal sector, to sustain the life of their families and themselves (Chen, 2014). The reason they are called as informal among others include: legality (no registration, no official tax pay etc), standard of products, and places of undertaking (can be at home, along street or at the sites of religious institutions etc. (Ralf and Farhad, 2013). As any other developing countries of the world and being one of the least developed countries, one of the serious concerns of all urban centers in Ethiopia is the extent of urban poverty and unemployment experience. In order to cope with the problem, the poor involve in prostitution, begging, borrowing, migration, and change in consumption pattern. The poor also engage in the urban informal sector to make their living as any other developing counnties of the world (Tegene,2012)

\subsection{Statement of the Problem}

The inability of the formal financial institutions to make funds available to reach the petty traders, due to the difficult conditions attached to loan has increased the relevance of the informal financial institutions such as money lenders, pawnbrokers, Rotating Saving and Credit Associations (ROSCA). According to Yusuf et .al (2009) the definition of informal finance pulls in such schemes as the operations of Rotating Saving and Credit Associations (ROSCA) which is known all over Africa as professional money-lenders. Informal employment occurs in various types and shapes, making it difficult to understand this complex Phenomenon. Similarly, levels of informal employment vary widely across countries, reaching the highest shares in sub-Saharan Africa, followed by Southeast Asia and Latin America. Livelihood in African cities has no longer revolved primarily on around wage earning jobs in the formal sector rather increasingly people earn their livelihood from informal wage labor or self-employment (ILO, 2006).

Street trading is one of the major occupations of the urban informal sector and petty traders are its main constituents. Petty traders in the urban informal sector help to provide goods and services to needy persons at the right time, in the right places, in the right quantities and at reasonable prices. They have become indispensable within the distribution system, catering to the needs of particularly the lower middle-class and the poor. There are, in fact, certain goods that are exclusively sold in the informal sector. In the process, this sector provides jobs to the jobless and offers fairly good remuneration to those largely unemployed before trading. Nonetheless, this sector receives little or no attention from policy makers and there exist serious cultural and funding challenges when it comes to accessing both formal and informal financial institutions. Because of informal employment can be a result of both people being excluded from formal jobs and people voluntarily opting out of formal structures.

In many middle-income countries people particularly the poor are increasingly involved in the informal sector to make living. Since the informal sector consisting of very small scale economic activities accounts for a substantial and increasing share of urban employment in most developing countries (Marthan, 2011). Evidences showed that in many developing regions a considerable proportion of town and city dwellers live on informal sector. For instance, informal sectors make 75\% of jobs in South Asia, 85\%of new jobs in cites of Latin America, $60 \%$ of urban labour force in Africa and 90\% of all new jobs in Ethiopia (Tipple, 2005; Degefa, 2008) In Ethiopia, the informal sector absorbs the majority of the urban unemployed growing labor force. It creates a wide employment opportunity for the marginalized groups especially women who are excluded from the formal sector due to little access and control over resources, lack of education, the presence of discriminatory laws, custom, and religious practices that has been exercised in the past and continues to the present (UNECA,2006; Darare, 2007).

This paper thus examines the financial constraints that access to credit and determinate of petty traders that prohibit them from becoming a formally or registered petty traders taking into account Jimma town in Oromia regional state of Ethiopia. The major factors are considered in light of, access to credit to the informal petty traders in study area, demographic factors, and credit policy such as collateral requirement, interest rate, 
bureaucratic process, license access, education and managerial ability, and recording skills etc. Understanding these constraints to micro-credit, commercial banks and non-financial institution access can inform policy adjustments; understanding the major determinate factors access to credit and the main factors that hinder them from becoming formal traders. Moreover, as per the researcher's personal knowledge there is no previously done research on the raised issue in the study area. This study therefore has attempted to contribute to filling the information gap by investigating determinant factors of finance on petty traders in the informal sectors; with particular emphasis on small café, fabricated shoes and cloth, vegetable and fruit informal petty traders in the Case of Jimma town, Oromia regional state, Ethiopia.

\subsection{Research Questions}

1. What are the major determinant factors in acquiring finance among petty traders?

2. What are the characteristics of petty traders in study area?

3. What are the factors that prohibit petty traders from becoming a formally registered trader?

\subsection{Objectives of the Study}

The main objective of this study is to identify and analyze determinant factors of finance among petty traders in the informal sectors in Jimma town, Oromia region of Ethiopia.

The specific objectives of the study that are fetched from the above research questions include:

1. To evaluate the major determinant factors in acquiring finance among petty traders.

2. To assess the characteristics of informal petty traders in study area.

3. To analyze factors that prohibit petty trader from becoming a formally registered trader.

\subsection{Review of Related Literatures}

Definition of informal sector enterprises

During its 15th ICLS, Hussmanns (2004) defined the informal sector enterprises on the basis of the following criteria: private unincorporated enterprise, i.e. enterprises owned by individuals or households that are not constituted as separate legal entities independently of their owners, and for which no complete accounts are available that would permit a financial separation of the production activities of the enterprises from the other activities of its owners; all or at least one good or service produced are meant for sales or barter transaction; their size in terms of employment is below a certain threshold to be determined according to national circumstances, and/or not registered under specific form of national legislation, and/or their employees are not registered; and Involved in non-agricultural activities, including secondary non-agricultural activities of enterprises in the agricultural sector.

The meaning of the term 'sector' follows the term used in SNA (1993). For national Accounting purposes, a sector (institutional sector) is different from a branch of economic activity (industry). It simply groups together similar kinds of production units, which in terms of economic objectives, functions and behavior have certain characteristics in common. The result is not necessarily a homogeneous set of production units. For the purposes of analysis and policy- making, it may thus be useful to divide a sector into more homogeneous sub-sectors. Informal sector enterprises as defined by the 15th ICLS are a sub-sector of the SNA institutional sector 'households. The term 'enterprise' is used here in a broad sense, referring to any unit engaged in the production of goods or services for sale or barter. It covers not only production units, which employ hired labor, but also production units that are owned and operated by single individuals working on own account as self-employed persons, either alone or with the help of unpaid family members. The activities may be undertaken inside or outside the enterprise owner's home, and they may be carried out in identifiable premises, unidentifiable premises or without fixed location. Accordingly, self-employed street vendors, taxi drivers, home-based workers, etc. are all considered enterprises.

The nature and characteristics of informal business operators; informal businesses are businesses that are not formally registered or at least violate one or more regulations (licensing, minimum wage, tax evasion and sanitation among others) of the central or local authorities (Jenkins, 2006). Harper (2006) says that informal business, in developing countries are notoriously difficult to count let alone to measure individually. On the other hand Santos (2008) and Musabayana (2006) observed that most informal businesses are small, mobile and labour intensive. He says most of them employ traditional methods of production, occupy temporary or mobile facilities and are small in size. Jerkin (2006) further argued that owing to these characteristics, informal business operators are less likely to enjoy credit from formal lending institutions. This therefore means that they cannot extend credit to their own customers. Santos (2008) observed the following characteristics of formal and informal business operators.

Santos (2008) pointed out that the major differences between formal and informal business enterprises are that, informal businesses are family based while large scale businesses are capital intensive and bureaucratic. Another notable difference is that customer relations are personal in the informal while it is impersonal in the 
formal enterprises. Thomas (2002) and Schneider \& Enste (2000) say the nature and characteristic of informal businesses are dynamic and the concept of informal business sector is still in debatable. They say, the most difficult is to make an agreement in setting definite boundaries between informal and formal sector. Peatie (1987) and Bromley (2000) argue that informal businesses are characterized by being individualistic in nature. Bromley (2000) refers to them as family self-employment. He said that the nature of informal sector is a necessary survival strategy in countries that lack social safety nets such as unemployment insurance or where wages especially in the public sector and pensions are low and such is the case in formerly called Rhodesia now called Zimbabwe.

The informal sector is universally viewed as providing the following benefits for developing countries (ILO, 2006): Serve as the spring-board for development by providing refugee for self-employed, talented and growth oriented entrepreneurs. Mobilize and utilize local development resources which otherwise could be wasted. Decentralize business activities and provide linkage between rural and urban communities and various branches of socio-economic establishments to meet people's needs at grassroots level. Contribute to equitable distribution and utilization of national resources. Stimulate entrepreneurial spirit the major sources of business funds for informal business whilst many business owners may not think beyond the local banks for their financing, Blanchard and Elkin (2008) remark that reality shows several alternative sources of financing for small businesses other than banks exist in normal economies. These other sources are often not considered because the business owners are too preoccupied with their day to day business to spend time on working out a financing strategy. Miller (2006) mentioned that owner's equity is an important source of financing for every business. Bankers like to see equity in business because it cushions for any loan they may make to the business since it does not have to be repaid as long as the business is surviving, neither does it carry any fixed rate of interest.

Jordan (2003) argues for and against both equity and debt financing. Merton, (2000) shares the same view by stating that the most important advantage of equity funding is that, unlike debt funding, equity funds typically do not have to be repaid on any strict payment schedule. Menton (2000) says equity investor's compensation is paid to investors in the form of dividends, but only if and when the business has made profit and that profit is not to be reinvested in the business.

\subsection{Research Methodology}

Based on( Watson, 2001) sample size determination formula, a representative sample of 182 was selected from three kebeles in the town

$$
\begin{aligned}
& \mathrm{n}=\left[\begin{array}{c}
\underline{\mathrm{P}(1-\mathrm{P})} \\
\frac{\mathrm{A}^{2}}{\mathrm{Z}^{2}} \underline{\mathrm{P}(1-\mathrm{P})} \\
\mathrm{N}
\end{array}\right] \\
& \mathrm{n}=\left[\begin{array}{c}
\frac{(0.5(1-0.5)}{0.05^{2}}+\frac{0.5(1-0.5)}{347}
\end{array}\right]
\end{aligned}
$$

$\mathrm{n}=182$

NB.Even if the selected sample respondents were 182, only 165 respondents were able to return the questionnaires sothat the actual number of respondents in the study area is 165 intead of 182.

\subsection{Data Analysis and Discussion}

1.7.1 Factors to acquire Finance

As it is well shown in the table below the relative majority of the respondents i.e $31.9 \%$ say lack of collateral security is the main impeding factor not to acquire finance from financial institutions $.19 .4 \%$ of the respondents stated that bureacratic process is the main hindering factor to aquire finance from financial institutions, followed by $18.1 \%$ who said it is lack of free loan service. I7.4\% said it is lack of awarness how to acquire finance and the remaining $7.6 \%$ and $5.6 \%$ of the respondents said it is interest rate and license requirement respectively that hinders them from acquiring finance. Based on the result of pearson chi-square value $(X=19.304, D F=10)$ has a positive significant association between access to finance and informal sector at $5 \%$ level of significance. 
Table 1: Major factors in acquiring finance to the respondents in reference with the informal sector type

\begin{tabular}{|c|c|c|c|c|c|c|c|c|}
\hline \multirow[t]{2}{*}{ SN } & \multirow[t]{2}{*}{ Category } & \multirow{2}{*}{$\begin{array}{l}\text { No. of total } \\
\text { respondent }\end{array}$} & \multirow{2}{*}{$\begin{array}{l}\text { Total } \\
\text { percent } \\
\%\end{array}$} & \multicolumn{3}{|c|}{ Informal sector types } & \multirow[t]{2}{*}{$\mathrm{X}^{2}$} & \multirow[t]{2}{*}{$\mathrm{DF}$} \\
\hline & & & & Small cafe & $\begin{array}{l}\text { Fabricated } \\
\text { cloth \& shoes }\end{array}$ & $\begin{array}{l}\text { Vegetables } \\
\text { and fruits }\end{array}$ & & \\
\hline 1 & $\begin{array}{l}\text { Collateral } \\
\text { requirement }\end{array}$ & 46 & 31.9 & $23(16.0 \%)$ & $12(8.3 \%$ & $11(7.6 \%)$ & $\begin{array}{l}19.30 \\
4 * *\end{array}$ & 10 \\
\hline 2 & Interest rate & 11 & 7.6 & $4(2.8 \%)$ & $4(2.8 \%)$ & $3(2.1 \%)$ & & \\
\hline 3 & $\begin{array}{l}\text { License } \\
\text { requirement }\end{array}$ & 8 & 5.6 & $2(1.4 \%)$ & $2(1.4 \%)$ & $4(2.8 \%)$ & & \\
\hline 4 & $\begin{array}{l}\text { Bureacratic } \\
\text { process } \\
\text { financial of } \\
\text { institution }\end{array}$ & 28 & 19.4 & $17(11.8 \%)$ & $7(4.9 \%)$ & $4(2.8)$ & & \\
\hline 5 & $\begin{array}{l}\text { No free loan } \\
\text { service }\end{array}$ & 26 & 18.1 & $6(4.2 \%)$ & $14(9.7 \%)$ & $6(4.2 \%)$ & & \\
\hline 6 & $\begin{array}{l}\text { No awarness how } \\
\text { to aquire finance }\end{array}$ & 25 & 17.4 & $12(8.3 \%)$ & $3(2.1 \% 0$ & $10(6.9 \%)$ & & \\
\hline \multicolumn{2}{|c|}{ Total } & 144 & 100 & $64(44.4 \%)$ & $42(29.2 \%)$ & $38(26.4 \%)$ & & \\
\hline
\end{tabular}

Source: Survey data 2017

\subsubsection{Sources of initial Capital for the Petty traders}

This study tried to assess the initial capital sources of the petty traders, accordingly it has been found that own saving is the primary source of capital for the petty traders followed by family contribution and lastly borrowing from friends and relatives. In addition, the standard deviation of initial capital and the selected informal business have positive association $\mathrm{DF}=2241.91$

Table2: Amount of initial capital and sources of finance for the respondents in reference to the informal sector type

\begin{tabular}{|c|c|c|c|c|c|c|c|c|c|}
\hline \multirow{2}{*}{$\begin{array}{l}\text { Initial } \\
\text { Capital } \\
\text { category }\end{array}$} & \multirow{2}{*}{$\begin{array}{l}\text { Total } \\
\text { respondent }\end{array}$} & \multirow{2}{*}{$\begin{array}{l}\text { Total } \\
\text { Percent }\end{array}$} & \multicolumn{3}{|c|}{ Informal sector type } & \multirow[b]{2}{*}{ Min } & \multirow[b]{2}{*}{ Max } & \multirow[b]{2}{*}{ Average } & \multirow[b]{2}{*}{ Df } \\
\hline & & & Small Cafe & $\begin{array}{l}\text { Fabricated } \\
\text { cloth and } \\
\text { shoes }\end{array}$ & $\begin{array}{l}\text { Vegetable } \\
\text { \&Fruit }\end{array}$ & & & & \\
\hline$<=500$ & 43 & 26.1 & $5(3.0 \%)$ & $9(5.5 \%)$ & $29(17.6 \%)$ & 200 & 10,000 & 2267.588 & 2241.91 \\
\hline $5001-2000$ & 43 & 26.1 & $19(11.5 \%)$ & $13(7.9 \%)$ & $11(6.7 \%)$ & & & & \\
\hline $2001-4000$ & 47 & 28.5 & $29(17.6 \% 0$ & $16(9.7 \%)$ & $2(1.2 \%)$ & & & & \\
\hline$>=4001$ & 32 & 19 & $20(12.1 \%)$ & $9(5.5 \%)$ & $3(1.8 \%)$ & & & & \\
\hline Total & 165 & $100 \%$ & $73(44.2 \%)$ & $47(28.5 \%)$ & $45(27.3 \%)$ & & & & \\
\hline \multicolumn{10}{|c|}{ Sources of finance category } \\
\hline $\begin{array}{l}\text { Borrowing } \\
\text { from friends }\end{array}$ & 15 & $9.1 \%$ & $4(2.4 \%)$ & $6(3.6 \%)$ & $5(3.0 \%)$ & & & & \\
\hline family & 42 & $25.5 \%$ & $25(15.2 \%)$ & $9(5.5 \%)$ & $8(4.8 \%)$ & & & & \\
\hline Own saving & 108 & $65.5 \%$ & $44(26.7 \%)$ & $32(19.4 \%)$ & $32(19.4 \%)$ & & & & \\
\hline Total & 165 & $100 \%$ & $73(44.2 \%)$ & $47(28.5 \%)$ & $45(27.3 \%)$ & & & & \\
\hline
\end{tabular}

Source:Survey data 2017

\subsubsection{Amount of Saving made by the Respondents}

Based on the survey result it was depicted that out of the total respondents $60 \%$ of them have no any type of saving account in the formal finacial institutions due to one or another of the following reasons as;insufficient amount of income,poor saving habit,lack of awarness how to open an account in the formal financial institutions. 
Table3: Saving account and amount of saving of the respondents in reference with the informal sector type

\begin{tabular}{|c|c|c|c|c|c|c|}
\hline \multirow[t]{2}{*}{ SN. } & \multirow{2}{*}{$\begin{array}{l}\text { Category of saving } \\
\text { account }\end{array}$} & \multirow{2}{*}{$\begin{array}{l}\text { Total } \\
\text { respondent }\end{array}$} & \multirow{2}{*}{$\begin{array}{l}\text { Total } \\
\text { percentage } \\
(\%)\end{array}$} & \multicolumn{3}{|c|}{ Informal sector type } \\
\hline & & & & Small cafe & $\begin{array}{l}\text { Fabricated clothes } \\
\& \text { shoes }\end{array}$ & $\begin{array}{l}\text { Vegatables } \\
\text { \&fruits }\end{array}$ \\
\hline 1 & Yes & 66 & $40.0 \%$ & $34(20.6 \%)$ & $21(12.7 \%)$ & $11(6.7 \%)$ \\
\hline \multirow[t]{2}{*}{2} & No & 99 & $60.0 \%$ & $39(23.6 \%)$ & $26(15.8 \%)$ & $34(20.6 \%)$ \\
\hline & Total & 165 & $100 \%$ & $73(44.2 \%)$ & $47(28.5 \%)$ & $45(27.3 \%)$ \\
\hline SN & \multicolumn{6}{|l|}{ If yes, amount saved: } \\
\hline 1 & $<100$ & 6 & $9.1 \%$ & $0(0.0 \%)$ & $4(6.1 \%)$ & $2(3.0 \%)$ \\
\hline 2 & $100-200$ & 19 & $28.8 \%$ & $9(13.6 \%)$ & $9(13.6 \%)$ & $1(1.5 \%)$ \\
\hline 3 & $300-450$ & 14 & $21.2 \%$ & $9(13.6 \%)$ & $4(6.1 \%)$ & $1(1.5 \%)$ \\
\hline 4 & $>450$ & 27 & $40.9 \%$ & $16(24.2 \%)$ & $4(6.1 \%)$ & $7(10.6 \%)$ \\
\hline Tota & & 66 & $100.0 \%$ & $34(51.5 \%)$ & $21(31.8 \%)$ & $11(16.7 \%)$ \\
\hline
\end{tabular}

Source: Survey data 2017

\subsubsection{Rationals of Respondents in Selecting the Informal sector type}

As per the result depicted, it was found that $30.3 \%$ of the respondents engaged in a particular informal sector assuming that it will give them better income than other businesses and $27.9 \%$ of them said that they engaged in the type of informal business due to the reason that they inherited such practices from their families and $27.3 \%$ of them said that is is due to the small capital it requires to start such a business. $7.9 \%$ of them said it is stability of the type of business they choose and the remaining $6.7 \%$ of the respondents selected their current job because it is the profession the know before.

Table4: Respondents reasons in selecting the type of informal sector

\begin{tabular}{|l|l|l|l|l|l|l|}
\hline SN & Category & $\begin{array}{l}\text { Number of total } \\
\text { respondent }\end{array}$ & Total \% & \multicolumn{3}{|l|}{ Informal sector type } \\
\cline { 4 - 7 } & & & $\begin{array}{l}\text { Small } \\
\text { Cafe }\end{array}$ & $\begin{array}{l}\text { Fabricated cloth } \\
\text { \&shoes }\end{array}$ & $\begin{array}{l}\text { Vegetables \& } \\
\text { fruits }\end{array}$ \\
\hline 1 & Family trend & 46 & $27.9 \%$ & $15(9.1 \%)$ & $14(8.5 \%)$ & $17(10.3 \%)$ \\
\hline 2 & Profession I know & 11 & $6.7 \%$ & $3(1.8 \%)$ & $6(3.6 \%)$ & $2(1.2 \%)$ \\
\hline 3 & $\begin{array}{l}\text { Gives better income } \\
\text { than others }\end{array}$ & 50 & $30.3 \%$ & $25(15.2 \%)$ & $18(10.9 \%)$ & $7(4.2 \%)$ \\
\hline 4 & $\begin{array}{l}\text { More stable than } \\
\text { others }\end{array}$ & 13 & $7.9 \%$ & $11(6.7 \%)$ & $2(1.2 \%)$ & $0(0.0 \%)$ \\
\hline 5 & $\begin{array}{l}\text { Less capital } \\
\text { requirement to start }\end{array}$ & 45 & $27.3 \%$ & $19(11.5 \%)$ & $7(4.2 \%)$ & $19(11.5 \%)$ \\
\hline Total & \multicolumn{2}{|l|}{165} & $100.0 \%$ & $73(44.2 \%)$ & $47(28.5 \%)$ & $45(27.3 \%)$ \\
\hline
\end{tabular}

Source: Survey data 2017

1.7.5 For how long a Petty trader stays in a particualar type of Informal sector?

As it is vividly shown in the table below the majority of the petty traders i.e $52.1 \%$ are new comers depicting that the trend toward being engaged in an informal activity is on the rise. Next $37 \%$ of the respondents are engaged in their current job for 3-5 years. $10.3 \%$ of them are engaged in their current job for $6-8$ years the remaining respondents were engaed in their current job for 9-10 years.

Table5: Years spent of the respondents in reference with informal sector type

\begin{tabular}{|l|l|l|l|l|l|l|}
\hline SN & Category & \multirow{2}{*}{$\begin{array}{l}\text { No. of total } \\
\text { respondent }\end{array}$} & \multirow{2}{*}{$\begin{array}{l}\text { Total } \\
\text { Percent(\%) }\end{array}$} & & & Informal sector type \\
\cline { 5 - 7 } & & & & Small cafe & $\begin{array}{l}\text { Fabricated } \\
\text { cloth \& shoes }\end{array}$ & $\begin{array}{l}\text { Vegetables \& } \\
\text { fruits }\end{array}$ \\
\hline 1 & $1-2$ year & 86 & $52.1 \%$ & $44(26.7 \%$ & $20(12.1 \%)$ & $22(13.3 \%)$ \\
\hline 2 & $3-5$ years & 61 & $37.0 \%$ & $22(13.3 \%)$ & $24(14.5 \%)$ & $15(9.1 \%)$ \\
\hline 3 & $6-8$ years & 17 & $10.3 \%$ & $4.2 \%$ & $3(1.8 \%)$ & $7(4.2 \%)$ \\
\hline Total & $9-10$ year & 1 & $0.6 \%$ & $0(0.0 \%)$ & $0(0.0 \%)$ & $1(0.6 \%)$ \\
\hline
\end{tabular}

Source: Survey data 2017

1.7.6 Types of support needed by the Petty traders

As the table below shows it vividly, $45.5 \%$ of the respondents said that construction of market place is the main support the need from goverment or NGOs out of this $23 \%$ respondents are small cafe petty traders due to the fact that by it's very nature it needs large work place than other types. $37.6 \%$ said that it is provision of credit which they need from supporters. Additionally, $8.5 \%, 4.8 \%$, and $3.6 \%$ of the respondents respectively said that provision of finance, training and development, and developing a working rules and regulation are the main 
types of assistance they are in need of.

Table 6: Types of support needed by the petty traders in reference with informal sector type

\begin{tabular}{|l|l|l|l|l|l|l|l|}
\hline $\begin{array}{l}\text { Informal } \\
\text { sector type }\end{array}$ & $\begin{array}{l}\text { No. of total } \\
\text { respondent }\end{array}$ & $\begin{array}{l}\text { Total } \\
\text { percent \% }\end{array}$ & $\begin{array}{l}\text { Provision } \\
\text { of credit }\end{array}$ & $\begin{array}{l}\text { Developing } \\
\text { rules } \\
\text { \&regulation }\end{array}$ & $\begin{array}{l}\text { Construction } \\
\text { of market } \\
\text { place }\end{array}$ & $\begin{array}{l}\text { Provision } \\
\text { of training }\end{array}$ & $\begin{array}{l}\text { Provision } \\
\text { of license }\end{array}$ \\
\hline Small cafe & 73 & 44.2 & $23(13.9 \%)$ & $0(0.0 \%)$ & $39(23.6 \%)$ & $2(1.2 \%)$ & $9(5.5 \%)$ \\
\hline $\begin{array}{l}\text { Fabricated } \\
\text { cloth \& } \\
\text { shoes }\end{array}$ & 47 & 28.5 & $14(8.5 \%)$ & $6(3.6 \%)$ & $20(12.1 \%)$ & $6(3.6 \%)$ & $1(0.6 \%)$ \\
\hline $\begin{array}{l}\text { Vegetable } \\
\text { \& fruits }\end{array}$ & 45 & 27.3 & $25(15.2 \%)$ & $0(0.0 \%)$ & $16(9.7 \%)$ & $0(0.0 \%)$ & $4(2.4 \%)$ \\
\hline Total & 165 & 100 & $62(37.6 \%)$ & $6(3.6 \%)$ & $75(45.5 \%)$ & $8(4.8 \%)$ & $14(8.5 \%)$ \\
\hline
\end{tabular}

Source: Survey data 2017

\section{Conclusions and Recommendations Conclusions}

Petty traders are highly indispensable in the distribution system providing useful services to the community especially the middle class and poor. There are certain commodities which are not capable of being sold to ultimate consumers by the formal sector such as fruits, vegetables, fabricated cloths and shoes etc.., and small fast food and drink services café that are not provided by the formal sectors. Petty traders have access to a large section of the urban community and do a very useful service to it at low cost of operation. The urban informal sectors are becoming the major source of petty traders for many people in both urban and rural areas of Ethiopia. This sector in Jimma town also provides large amount of jobs mainly to the poor and other impoverished groups' of the society. Thus, the study examined determinant factors of finance for petty traders in the informal sectors in Jimma town. And identified the characteristic of petty traders and the main factors of petty traders to acquire finance and analyzed factors that influence or prohibit petty traders from joining formal sectors. The study adopted both quantitative and qualitative approaches using questionnaires and observation in the study area. Based on the survey study, out of the total respondents, the majority of the petty traders are female and single and came out side of Jimma town due to lack of job opportunities, marriage , family displacement, following relative friends, and education of the petty traders. There are various difficulties' in establishing the informal sector business of those petty traders; these includes lack of initial capital, lack of operating places, lack of collateral and lack of raw materials.

\section{Recommendations}

Informal sectors play a significant role in the socio-economic development process of poor countries like Ethiopia. Despite the significant role of the sector in reducing unemployment and in the fight against poverty, the sector in general and participants in particular has not been getting support and recognition from government and policy makers. Based on the findings the researcher forwarded some recommendations so as to come up with an improved circumstances for informal petty traders. Firstly, better access to financing have to be devised by the concerned parties since limited access to funds is one of the major factors explaining the development of the informal economy, secondly, government awarness have to be there about the importance of the informal sector in contributing to the national GDP specially policy makers in the country should recognize the important role the informal sector plays in the economy. Third improving acces to information, the fact that the informal sector has been neglected by policy makers has not helped in generating knowledge on this sector, for instance informal activities are often invisible in official statistics.

\section{References}

Aryeetey, E. and C. Udry. 2007. "The characteristics of informal financial markets in Sub-Saharan Africa". Journal of African Economies, supplement to vol. 6. Number 1.

Chen, V. C. (2014). Mainstreaming Informal Employment and Gender in Poverty Reduction. London: Commercial Wealth Secretariats

Helmising, A. H. J. (2003). Small enterprise and industrialization policies in Africa: Small Enterprise and Changing Policies, SRP.

Harper, M. (2006). Small Business in the Third World. New York: John Wiley and SonsJenkins, J. (2006).

Kiggundu, M. (2002). Entrepreneurs and entrepreneurship in Africa: What is known and what needs to be done. Journal of Developmental Entrepreneurship (7): 3, pp. 239 - 258 Mandizvidza, C. (2010). The activities and development of the informal food retail sector: A study of tuck shops in Harare: Harare: University of Zimbabwe.

Oloyede, J. A. (2008). Informal Financial Sector, Savings Mobilization and Rural Development in Nigeria: 
Further

Mutambara, A. (2009). Boosting investor confidence in Zimbabwe; The Herald, B6; 26 March 2009.

Saito, K. A. (2008). Raising the Productivity of Women Farmers in Sub -Saharan Africa. World Bank Discussion Papers No. 230. World Bank, Washington DC.

Tegegne G/Egziabhir (2012). Perspective and Issues of Urbanization Development in Ethiopia 